\title{
WHAT WENT WRONG WITH THE VEIL? A Comparative Analysis of the Discourse of the Veil in France, Iran, and Indonesia
}

\author{
Dian Maya Safitri \\ Center for Religious and Cross-cultural Studies (CRCS), Gadjah Mada \\ University Yogyakarta, Indonesia
}

\section{Abstract}

This paper attempts to discuss several current issues about the veil. Three countries are selected, namely France, Iran, and Indonesia, due to their different policies and perspectives concerning the veil. Using discourse analysis, this paper examines the violation of human rights, particularly those of Muslim women, by the ban of the veil in France and the obligation to wear it in Iran. Finally, inspired by the theoretical work of Gramsci, this paper analyzes how the terms "secular" and "religious "are used by the state to justify their hegemony over certain minority groups. Moreover, this paper offers the "correct concept of secularism" as that entails civic reason, constitutionalism, and human-rightsbased citizenship, and proposed by $\mathrm{An-Na}$ 'im as the best avenue to safeguard the problem of human rights in France and Iran. The rest discussion of this paper discusses Indonesia, the largest Moslem country in the world, that is, in fact, "a secular country" based on Pancasila, which respects religious freedom, including for women to wear the veil or not. It also opens full, equal, and fair access for all Indonesian women, regardless of their ethnicity and religious affiliation, to compete in the workforce and to pursue education. The author's intention is to clarify false stereotypes about the veil, to enlighten readers about abuse of power by both French and Iranian governments in violating the rights of women on the issue of veil, and to inform readers --using the case of Indonesia as an example-- about the importance of state neutrality in supporting the rights of freedom of and from religion. 
Keywords: veil, human rights, Muslim women, laïcité, shari' $a$, secularism

\section{A. Introduction}

Discourse about the veil today is always controversial and sparks a dichotomy between persons who support the veil and those who oppose it. ${ }^{1}$ Some Westerners have simplified the issue of the veil to oppression by the male-dominated world in Islam, while others, particularly some Muslim women, contend that it is a symbol of women's liberation and piety. In addition, there is also the unavoidable phenomenon of "the Islamic resurgence" which has emerged since the late 1970s with deep influence over religion, politics, and society in the rest of the Islamic world. ${ }^{2}$ At the same time, the Muslim world must also face the unavoidable secularization through globalization, modernization, technology, media, and economics. Usually, much of this influence comes from Western countries. These contradictory influences have triggered the widespread Islamophobia and Western paranoia on this globe between two competitive poles of Muslim and non-Muslim societies.

Furthermore, the dispute over the veil is an important phenomenon to observe, because it does not only involve religious precepts, but also the political interests behind it. The concept of the veil gradually mutates to encompass women's bodies, privacy, counter-culture, law, "nationalism", the state, human rights, and even Huntington's "clash of civilization". France and Iran might be the perfect representations for the tension between the West/Secularism versus East/Islam. The state, which is supposed to be the leading pro-human rights organ, on the contrary, has benefited the law. In this case, as mentioned by Bourdieu, there is a tendency to transform the law into the means for a "field of control". In those two countries, the states intentionally give false definitions for the words "secularism" and "Islam" to their people in order to justify their political advantage.

${ }^{1}$ The author would like to express gratitude to Dr. Amina Wadud who has given useful advice on how to develop and organize the theme of the discourse of the veil and to give credit for Brittanny Jordan and Emma Nolan-Thomas for peer reviewing this paper.

${ }^{2}$ Suzanne Brenner, "Reconstructing Self and Society: Javanese Muslim Women and the Veil", American Ethnologist, Vol. 23, No. 4 (1996), p. 673. 
Therefore, neither the laïcité of France nor the Velayat-e-Faqih model from Iran is suitable for advocating the freedom of and freedom from religion and belief regarding the veiling discourse, due to their exclusiveness from diversity and the impossibility of civic reason. The most appropriate style for human rights-based citizenship is An-Na'im's version of secularism, which is applied by Indonesia via its "Pancasila principles".

\section{B. What is the Veil?}

There is no essential definition for the term "the veil". Heterogeneous Muslim cultures and traditions have created various meanings for the word "the veil". Khaled Abou El Fadl ${ }^{3}$ labels the veil as al-hijab, which compels women to cover their entire body except for the face and the hands. For Carl W. Ernst, hijab is defined as "the curtain" as stated in Qur'anic verses: "When you ask them [the prophet's wives] for something, ask them from behind a curtain (33: 53). Later, this kind of hijab became the notion of veiling, though at that time it concerned the Mohammed's wives only. Historically, Muslim women imitated the customs of upper-class Persian, Greek, Roman, and Jewish women as the benchmark of their religious conduct. They wore the veil to evade men's gaze in the street. This phenomenon is evidence of the development of the function of the veil: from the curtain for the wives of the Prophets to the covering clothing worn by "decent" women, especially those who inhabit cities. ${ }^{4}$

Meanwhile, according to Katherine Bullock, the term "bijab" stems from the Arabic (which has the root hajaba) meaning "to cover, conceal, hide, a complex notion encompassing action and apparel". It means that one has to lower one's stare and cover one's body from navel to knee and it comprises covering the face or not. Nowadays, hijab refers to the headscarf that women wear over their heads and tie or pin at the neck without enveloping their face. ${ }^{5}$

${ }^{3}$ Abou Khaled El Fadl, Speaking in God's Name: Islamic Law, Authority, and Women (Oxford: Bell \& Bain, 2001), p. 102.

${ }^{4}$ Carl W Ernst, Following Muhammad: Rethingking Islam in the Contemporary World (London: the University of North Carolina Press, 2003), p. 148.

${ }^{5}$ Katherine Bullock, Rethinking Muslim Women and the Veil (Richmond: The International Institute of Islamic Thought, 2003). 
Some researchers and authors on Islam, such as Suzanne Brenner (who conducted research in Java), employ the word "veiling" instead of "the veil", referring to "the practice in which a woman covers her head (usually also covering her hair and neck-although rarely her face) and all of her body except her hands". ${ }^{6}$ In Indonesia, Brenner figured out that the veil is translated as jilbab, which implies the Islamic style-clothing for either head covering or all-enveloping Islamic cloth. Jilbab, at the beginning, was designated as the newer style of Islamic clothing imported from the Middle East and used by mostly young women to contest the traditional sarong, kebaya, and loose headscarf or woven cap worn by older Indonesian women. Due to the globalization and modernization which has caused Islamic women to dress up "fashionably", today the jilbab is no longer identical with the Middle Eastern clothing. Many Indonesian women amalgamate traditional and foreign clothes with jilbab to look more attractive, stylist, but still well-suited within the Islamic tenets about modesty. Additionally, the increasing number of women who wear jilbab in Indonesia has contributed to the progress of Islamic fashion from time to time. ${ }^{7}$

Nevertheless, following Ernst, the misleading stereotype about the veil as the icon of repression in Islamic world has occurred as a result of associating the veil with the sort of women's clothing in Iran, Arabia, or Afghanistan. In Iran, women are required to wear the Iranian chador or "a black drape that envelops the body, with the exception of the face and hands". ${ }^{8}$ Recently, in the Teheran, it can be substituted by a raincoat and a headscarf called a manteau. ${ }^{9}$ Moreover, they are not allowed to apply facial makeup. Likewise, according to Ernst, the Afghan government mandates that Pusthun women must follow their traditional tribal code,

${ }^{6}$ Suzanne Brenner, "Reconstructing Self and Society", p. 691.

${ }^{7}$ For detailed information regarding "politics of the veil" for economic interest all over the world, see Patrick Haenni, "l'Économie Politique de la Consommation Musulamanne” at http://religion.info/pdf2008_11_consommation:pdf.

${ }^{8}$ Ernst, Following Muhammad, p. 147

9 This word is originated from French. Manteau is usually accompanied with "rosary" or a scarf. These two things have created so-called "bijab chic". Faruqui also demonstrates that the globalization and modernization in Iran has resulted in more liberal expression among Iranian women via their colorful rosary. Some of them even modify it so that they can show off their hair. See Munis D. Faruqui, "Iran: Renegotiating a 'Revolutionary Identity", Economic and Political Weekly Vol. 33, No. 31 (1998), p. 2071. 
namely the all-encompassing burqas. The chador and burqa are not similar to the abaya, which belongs to Arabian women.

In Western countries, the veil is known by various names. French people translate "the veil" as le foulard or le voile which is associated with the headscarf related to the Arabic immigrants who belong to the Berber and Arab ethnicities. Some French pro-republicans also argue about whether the bandana can be associated with the veil or not. The controversy over the ban of such headscarves-known as l'affaire du foulard-has been a major issue of the state recently. Similarly, even more tolerant European countries like England, whose immigrant Muslims come from the Commonwealth, like Indians and Malaysians, are dealing with similar disputes. However, the problem in England concerns the niqab, which covers a woman's entire face except her eyes. The Netherlands, which has become home to Muslims from the Balkans and Indonesia, is also attempting to prohibit the burqa, not the veil. ${ }^{10}$

Despite all debates regarding "the veil", actually the Qur'an itself does not mention a rigid definition of the word "the veil". The Qur'anic verses only mention the rule for Muslim women to dress modestly and lower their gaze (24:31, and 33: 59). It is the conception of "modesty" and God's commandment not to "display their (women's) beauty" which provokes many interpretations among Muslim scholars. ${ }^{11}$ The first group — as noted by Poulter-believes that covering the hair and neck represents "modesty". Meanwhile, another group insists that "the women's beauty" in Qur'an refers to the entire face. This interpretation is held by a minority school of thought. Saudi jurists even require the covering of everything excluding the eyes or one eye. ${ }^{12}$ The rest reject covering either their hair, neck, or face since they argue that they are part of the "ordinary appearance of women". ${ }^{13}$ Though they do not wear the veil, adherents of this understanding choose loose-fitting clothing, which covers their body, and avoid tight and transparent garments.

${ }^{10}$ Joanne Wallach Scott, The Politics of the Veil (Princeton: Princeton University Press, 2007), pp.1-3.

${ }^{11}$ Sebastian Poulter, "Muslim Headscarves in School: Contrasting Legal Approaches in England and France", Oxford Journal of Legal Studies, Vol. 17, No. 1 (Spring 1997), p. 46.

${ }^{12}$ Abou Khaled El Fadl, Speaking in God's Name, p. 104.

${ }^{13}$ Afshar, as cited by Sebastian Poulter, "Muslim Headscarves in School", p. 46. 
Furthermore, according to Khaled Abou El Fadl, the veil aims at preventing human beings from fitnah, which is considered by some people as the particular acts producing the type of sexual stimulation that is conducive to the commission of sin. In Islamic discourses themselves, fitnah is associated with chaos, disorder, inducement, and the opening of the doors to evil. Moreover, the Qur'an is more likely to use the term fitnah as the cause of ordeals and problems, such as money, rather than the origin of sexual seduction. ${ }^{14}$

El-Fadl also stated that early Islamic reports demonstrate that the veil has to do more with social status and physical safety than fitnah. In accord with social status, in Indonesia wearing the veil can be connected with prestige, e.g. to be respected as hajj, to be recognized as the daughter or the wife of prominent Islamic leaders in kampong, to be identified as the head of particular Islamic organizations or parties, and so forth. Meanwhile, the reason of safety is correlated with the awrah or, as defined by El Fadl, what is considered as the private parts which ought to be covered by clothing. Similarly, Suzanne Brenner explains the term awrah by referring to the affirmation of Leila Ahmed: "blind in one eye, blemished, defective; the genital area; generally parts of the body that are shameful and must be concealed; women's bodies; women's voices; and women". ${ }^{15}$ Thus, Saba Mahmood ${ }^{16}$ adds that women should 'hide their charms' when in public to prevent the libidinal energies of men who are not the members of their kinship.

This moral issue is one of the ultimate reasons for Muslim women to wear the veil. The research conducted by Suzanne Brenner about Muslim women wearing the veil in Java reveals that the veil serves as: (1) both the embodiment and ensoulment ${ }^{17}$ of religious piety, (2) Muslim identity around the world, and (3) the reconstruction of the society

\footnotetext{
${ }^{14}$ Abou Khaled El Fadl, Speaking in God's Name p. 232

${ }^{15}$ Suzanne Brenner, "Reconstructing Self and Society", p. 692.

${ }^{16}$ Saba Mahmood, Politics of Piety: the Islamic Revival and the Feminist Subject 2005
} (Princeton: Princeton University Press, 2005), p. 50.

${ }^{17}$ See Talal Asad, Reading a Modern Classic: W.C. Smith's The Meaning and End of Religion (Chicago: University of Chicago Pres, 2001), p. 218. This term is coined by Talal Asad which refers to the potential capability of the living body to use its emotional pain to cultivate righteous stance. Moreover, embodiment is denoted in the sense "human action and experience are placed in material body". 
via individual and communal self-discipline. Besides, as revealed by Katherine Bullock's enterprise in Canada, Muslim women regard the veil as a vehicle for combating male harassment, gaining respect from men, and countering old Western conceptions of beauty. Another different motive to take on the veil, which is usually adopted by Arabic women, is grounded in pride of the original Arabic traditions and the motivation to perpetuate this "veiling tradition" for their daughters.

Unfortunately, as affirmed by Carl W. Ernst, the false notion from the Western world which associates the veil with "the backwardness" has widened the gap between Islamic and Western cultures. In the past, such an excuse was even used as justification by Europeans to invade Asia and Africa, so that they could set "these oppressed veiling women" free and lead them to modernity. They insisted that Muslim women could become "civilized" if they took off their veil. In this postcolonial era, there is a tendency to recognize that the ban of the veil has to do with a misunderstanding of Islam in European countries, such as France. It also bared the way for the increasing Islamic thrust as well. In addition, the Western mass media has excessively exposed skewed judgments about Muslim women as passive, repressed, and marginalized victims within "the Islamic communities". Thus, Westerners assume that these "miserables" need "Western heroes" to liberate them. ${ }^{18}$

From such narrow conceptions, it seems that these Westerners ignore the Enlightenment brought by Muslims, which saved Europeans from the darkness. They also reject the tokens about the significant roles played by many veiled Muslim women all over the globe in this modern era, even in the Western world. For example, Mahidur Özdemir, ${ }^{19}$ who became the youngest member and the first veiled women in the Belgian Parliament, Yvonne Ridley, the former British journalist who converted to Islam, three veiled Indonesian women who were the recent winners

${ }^{18}$ Lila-Abu-Lughod, "Do Muslim Women Really Need Saving? Anthropological Reflection on Cultural Relativism and Its Others", American Anthropologist, Vol. 3, No. 104 (2002): pp. 783-790; as cited by Sakhroni, "Shirin Ebadi, Transcender of Divisive Boundaries", ISIM Newsletter, Vol. 13 (December 2003), pp. 6-7.

19 "Mahinur Özdemir (CDH): "On me diabolise à cause de mon foulard", Election, May 2009. 
of L'Oreal Indonesia Fellowships for Women in Science, ${ }^{20}$ and many other Muslim women. Currently, it is also common to see veiled Muslim studying in the world's top-ranked universities like Harvard, Oxford, Yale, Cambridge, Leiden, and other prestigious scholarly institutions. Nevertheless, Westerners, Europeans in particular, keep arguing that the removal of the veil will lead Muslim women into "advancement" and "modernization".

\section{What is Behind l'affaire du foulard in France?}

The following explanations will describe the headscarf controversy in France that has been an international issue since the Creil tragedy, and also uncover the hidden motive behind it. As proven by Joan Wallach Scott, in her extraordinary work, The Politics of the Veil, the headscarf controversy (l'affaire du foulard) is primarily caused by the racist frenzy of Jean-Marie Le-Pen's followers and their anti-immigrant ideas. Le Pen was the leader of the National Front party, which often publicly expressed xenophobia. For him, the veil is not only linked with the 9/11 tragedy, murders, and bombings in Europe, but also with the ethnic/cultures coming from Magbrébien. ${ }^{21}$ The French government is still haunted by the memories of the Algerian revolutionaries, who took advantage of veiled women to carry messages, money, grenades, and weapons to guerilla soldiers who were trying to free the country from the French in 1958. In this case, the resistance over imperialism, of which Scott also

20 "Tiga Perempuan Peneliti Indonesia Raih 'for Woman in Science", Kompas, December 2009.

${ }^{21}$ Scott elaborates that Maghrébiens (Maghreb is derived from Arabic word which means "The western direction") are the people from Algeria, Morocco, and Tunisia in North Africa which used to be the French colony and protectorates. However, such a label is likely to be associated more with the Arabs who inhabited those countries, mainly Algeria. The black people from Algeria who today reside in Europe are called les pieds noirs (literally imply "the black feet"). Though the Berbers are another ethnic group originating from Algeria, their European looks, plus the increasing numbers of Berberian-Christian converts, have made it easier for them to "integrate" with the French. Therefore, the Berber clan has a higher social level than the Arabs. Parallel to Scott's depiction, Cesari as cited in Bowen 2005, 330) highlights the discrimination against Muslims born in France (les beurs) by the government and environment through the ascribed-status given to them either as "Maghrébien", "Arabs", or "Muslims". It seems that they will never be fully accepted as "French". 
spoke, was manifested through the donning of the veil. The "crusade" between Algerian-Arab-Muslims with the French-Christians continued when Colonel Boumedienne, the nationalist Algerian President, claimed that Algeria was an Islamic nation. Accordingly, Algerian women must not copy Western (French) culture. Such a statement was "a revenge" for Charles de Gaulle's argument in 1959 that made the analogy of French and Arabs being like oil and vinegar: these two societies would never be united.

At the present time, this anti-immigrant sentiment is inherited from French predecessors to the Republican ruling elites by using laïité principles as an alibi. Laïcité is "the French version of secularism". ${ }^{22}$ This refers to the total division between the state and religion. The state works hard to create a "universalism" or sameness of all individuals (La droit à la resemblance). ${ }^{23}$ Consequently, particular religious societies can lose their freedom of religion or belief. The antonym of "universalism" is "communalism" (communautarisme), as adopted by the United States, or other types of secularism, which safeguards both religion and atheism from intervention by the state. This has fostered pluralism (la droit à la difference) in United States.

Historically, the headscarf controversy appeared for the first time in 1989 in Creil, a city located in northern France. ${ }^{24}$ At that time, three veiled girls were expelled by Eugène Chénière, the headmaster of a school in Creil. Next, it is hard to disagree with Joan Wallach Scott's analysis that the controversial bill of veil prohibition has to do with the political game. After "his merit" in imposing "the principles of laïcité" to the immigrant girls, Eugène Chénière became the deputy from the Raillement

${ }^{22}$ Joan Wallach Scott, The Politics of the Veil, p. 15

${ }^{23}$ Poulter reveals that the French government defends itself in the sense of "anti-pluralism" by appointing the jargon of Jacobin as the foundation of the country: "La République est une et indivisible (the Republic is one and indivisible)". This requires each citizen to prioritize the "Republican identity" and marginalize one's individual's persona, such as religion, ethnicity, language, etc. The state of France never gave any clear standard for what kind of "Republican identity" must be possessed by its people. But, in fact, this is in conflict with the French Declaration of the Rights of Man and of the Citizen 1789 which guarantees equal protection for all citizens before the law and also the famous motto of the French Republic: Liberté, Egalité, Fraternité (Freedom, Equality, Brotherhood).

${ }^{24}$ Sebastian Poulter, "Muslim Headscarves in School", p. 43. 
pour la Républic in 1994. He offered a controversial bill for the prohibition of all "conspicuous (ostentatoire)" signs, which was supported by François Bayrou, The Minister of National Education. As a result, Bayrou outlawed "conspicuous" signs and permitted only "discreet" religious symbols in schools. The third period of the headscarf controversy began in 2003 and was triggered by a proposal from Nicolas Sarkozy, the minister of the interior, requiring an unveiled pose of Muslim women for formal identity photographs. Finally, the government endorsed the law prohibiting the veil in public schools on March 15, 2004:25

In public elementary, middle and high schools, the wearing of signs or clothing which conspicuously manifests students' religions affiliations is prohibited. Disciplinary procedures to implement this rule will be preceded by a discussion with the student.

The clothing and religious signs prohibited are conspicuous signs such as a large cross, a veil, or a skullcap. Not regarded as signs indicating religious affiliations are discreet signs, which can be, for example, medallions, small crosses, stars of David, hands of Fatima, or small Korans.

This implausible regulation is certainly worth examining. It is the term "conspicuous" which has been generating worldwide debate recently. For Poulter, the French government circumscribes "conspicuous" as the icons of proselytism or indifference. It is obvious that this law is intentionally created only for veiled women, because it allows for the donning of small crosses, which are regarded as "discreet" religious symbols. In fact, the French government cannot answer several questions. Who has the right to determine whether a veil is "conspicuous" or not? How do the teacher and the state decide which students are wearing the veil for fashion, tradition, or conviction? If religion is not compatible with laïcité, then why are small crosses permissible? Why do Muslim women become the "target" for the enforcement of this law instead of men who have more vicarious "conspicuous" insignia, namely the beard? How do Maghrébien girls plan to engage in proselytism or endanger the laïcité only with their veil?

In addition, the statement "disciplinary procedures to implement this rule will be preceded by a discussion with the student" is not true. Many cases show that the school and the state choose "the coercive

\footnotetext{
${ }^{25}$ Joan Wallach Scott, the Politics of the Veil, p. 1.
} 
power" to expel the veiled girls from school rather than "discussing the law" with them. Thus, by observing this unjust law, no wonder that Dennis Pelletier describes it as "the exceptional law". ${ }^{26}$ This has strengthened my aforementioned thesis that the headscarf controversy is the manifestation of French government exclusivity over their former colonial territories' traditions and religion.

\section{Velayat-e-Faqih, the Theocracy or Clergy Authority?}

The Islamic Republic of Iran declares that they apply theocracy as their political system. Cherabi explains that it implies "God is recognized as the immediate ruler and God's laws are taken as the legal code of the community and are expounded and administered by holy men as God's agent". ${ }^{27}$ Such a model is supported by velayat-e-faqib or the guardianship of a Supreme Leader who is a prominent cleric appointed based on "his" knowledge of figh and regiopolitical record. He serves as the guide for Iranians under God's justice. ${ }^{28}$ Besides, there are also marja chosen by the Iranian people to be "role models". ${ }^{29}$

Nevertheless, many prominent Islamic scholars, such as AnNaim, hesitate regarding the purity of "God's laws" in shari" $a$-based countries. According to him, shari' $a$ is not a godly paradigm, but a human interpretation of the divine. Therefore, as there is a tendency that the religious realm will be influenced by personal views, it is important to keep the religious neutral..$^{30}$ The menace of the "politization of religion"31 and the tendency of misusing the law by the patriarchal and authoritarian

${ }^{26}$ Pelletier, Dennis, "l’École, l’Éurope, les Corps: la laïcité et le voile”, Vingtième Siècle, Revue d’histoire. Numéro Spécial: laïcité, séparation, sécularisation 1905-2005, No. 87 (Jul-Sept 2005), p. 162.

${ }^{27}$ H.E. Cherabi, "Religion and Politics in Iran: How Theocratic is Islamic Republic?”, Daedalus, Vol. 120 No. 3 (1991), p. 69.

${ }^{28}$ Bakman Baktiari, "Dilemmas of Reform and Democracy in the Islamic Republic of Iran," in Robert W. Hefner (ed.), Remaking Muslim Politics (Princeton: Princeton University Press, 2005), p. 114.

${ }^{29}$ H.E. Cherabi, "Religion and Politics in Iran", p. 69.

${ }^{30}$ Abdullahi Ahmed An-Na'im, Islam and the Secular State: Negotiating the Future of Shari'a (Cambridge: Harvard University Press, 2008), p. 85.

${ }^{31}$ Pratap Bahnu Mehta, “On the Possibility of Religious Pluralism”, in Thomas Banchoff (ed.), Religious Pluralism, Globalization, and World Politics (New York: Oxford University Press, 2009), p. 87. 
regime ${ }^{32}$ justifies An-Naim's proposal about the separation between the state and religion. But, religion still can influence politics and enter the public sphere.

In relation to Iranian women, the state draws boundaries between "religious" and "non-religious" women by imposing the typical Iranian veil named chador. Even non-Muslim women are obligated to wear a chador. In almost all public places, we can find many signs about the order to dress up according proper Islamic norms of "bijab" because bad "bijab" equals disloyalty to their husbands. They are not allowed to apply cosmetics. If they break the law, basij ${ }^{33}$ will warn them. ${ }^{34}$

Similar with French's laïcité, which resists immigrant traditions, the main reason for compelling chador, according to Faruqui, is to prevent the penetration of "westernotoxification". Yet, there are no clear explanations from the Iranian government about what kind of western influences are "poisonous" for the state and how effective the chador is to handle "bad western influences". Contrastingly, such a law generates a paradoxical reality among young people. The extreme limitation against "western clothing", followed by the division between men and women in public spaces has caused private parties where the sexes can share alcoholic beverages and close relationships. ${ }^{35}$ As this example shows, the obligation to don the veil remains ineffective.

In addition, the compulsion to take on the veil per se contradicts the Islamic tenet which affirms that there is no coercion in religion (2:256). The abuse of religious freedom in this law is incompatible with the principle of Islam as rabma lil-alamin (compassionate and justice for all mankind). Thus, the Iranian interpretation of "Islamic justice" is contestable.

This law also shares the same notion of "universalism" like in France. It means that all distinguished people must have a "single identity", namely the "Iranian Muslim identity", and are unable to express their own tradition and religion, the non-Muslim faith in particular. This is in opposition to the Qur'anic verse which emphasizes tolerance: p. 1406.

${ }^{32}$ Madhavi Sunder, "Piercing the Veil," The Yale Law Journal, Vol.112 (2003),

${ }^{33}$ A volunteer-based extra-military arm of the government.

${ }^{34}$ Munis D. Faruqui, "Iran: Renegotiating”, p. 2071.

${ }^{35}$ Bakman Baktiari, "Dilemmas of Reform", p. 126. 
O Mankind! We have created you male and female, and have made you nations and tribes so that you might (affectionately) come to one another... $[\ldots](49: 13)$

It is obvious that God intentionally creates different human beings so that we all learn to respect each other. If God is indeed omnipotent, it would be easy for God to make this entire world with a unique culturebased Muslim population. Yet, homogeneity will never teach us how to unite in diversity. The Iranian state and clerics ignore this and keep imposing the "Islamic teaching" for their own contingency.

Furthermore, like France, the Iranian government cannot clarify why there is no "bijab regulation for men." It seems that it is only women who have to "fight against" the Western infiltration by wearing the veil. In other words, stemming from Saba Mahmood's standpoint ${ }^{36}$ the concept of "modesty" is the construction made by patriarchal evaluations, images, and representations over the subjection of women's bodies. Paraphrasing Beauvoir's concept, men define women as "the other" to subordinate the position of women. In the case of the compulsory hijab in Iran, the state uses what Saba Mahmood labels as a "politics of piety" to demonstrate the male "socio-political control" over Muslim (and nonMuslim women). The state takes advantage of the word "religion" to make "borders" between "the west" and "us". Such a misleading paradigm has transformed the original essence of shari 'ah from sources of moral norms and values via a democratic political process ${ }^{37}$ into a daunting biased law enforced by a "religious" institution. Accordingly, the Iranian state model is inapplicable in the modern era due to its inferiority and violation of women's religious freedom in velayat-e-faqih.

Civic reason refers to the entitlement given to all citizen and social actors to express their opinion publicly. The state can adopt their opinions in the formulation of public policy or legislation. However, the state must be an agency independent from the intervention of any particular group. This civic reason must be guarded by the underlying function of constitutionalism which will guarantee that the views and interests of citizens are well served by the ruling elites. ${ }^{38}$

\footnotetext{
${ }^{36}$ Saba Mahmood, Politics of Piety", p. 158.

${ }^{37}$ Abdullahi Ahmed An-Na'im, Islam and the Secular State, p. 1.

${ }^{38}$ Ibid., p. 93-103.
} 
Both France and Iran have failed to facilitate civic reason for several reasons. First, particular societies have taken over the formulation of public policy. In France, it is the secular group that possesses hegemonic power, whereas in Iran, the clergy's views are dominant. Such nonneutral states have closed the possibility for accountable and transparent constitutionalism.

Second, the state authorities in France and Iran have dismissed the opportunity for human-right-based citizenship proven by the exclusive identity constructed by the government. The refusal of "communalism" in these two countries paves the way for a mutual relationship between the state and the diverse social actors. As a result, the minority group is marginalized by the majority.

Lastly, both laïité and velayat-e-faqih are not concerned with the dynamic set of values in constitutionalism, which can be perceived through a trial-and-error process. For them, the notion of constitutionalism and even human rights are only abstract ideas, or worse, pieces of papers, because the government does not take tangible action for developing human rights. For instance, French leaders still hold xenophobic perspectives which block the progress of human rights. Likewise, the confiscation of Shirin Ebadi's ${ }^{39}$ Nobel award ${ }^{40}$ has sealed the door toward human entitlement in Iran.

In sum, the above-mentioned explanations show the difficulties for civic reason in French and Iranian governments. As the state is not autonomous, the majority have discriminated against the minority, and the foundation of France and Iran ignores the value of human rights, so that their people cannot rely on the state to enjoy democracy.

\section{E. Indonesian Pancasila: the Middle Way}

I will begin this part by listing the five principles of Pancasila, which are the most important pillars of law in Indonesia. They are: (1) monotheism, (2) humanitarianism, (3) national unity, (4) representative

\footnotetext{
${ }^{39}$ Human right activist in Iran

40 "Iran Sewot Terima Kritik Penyitaan Hadiah Nobel," Kompas, November $27,2007$.
} 
democracy by consensus, (5) social justice. ${ }^{41}$ Amin Abdullah ${ }^{42}$ and Suhadi Cholilit ${ }^{43}$ stated that Pancasila has successfully accommodated theist and anti-theist leaders in Indonesia because religious values are regarded as the foundation of Indonesian law, yet particular religions cannot intervene the state. To some extent, this really fits Cassanova's dictum about the "deprivatization" of religion, i.e. religion can enter the public dimension of modern societies. It also supports Peter L. Berger ${ }^{44}$ who argues that religion and secularism should not be trapped in a "zero-sum" situation, and have to embrace reciprocal altruism instead.

However, while the concept of "one God" is the first principle of Pancasila, practically the Indonesian government has made positive progress related to the "freedom of" and "freedom from" religion ${ }^{45}$ from the Soekarno era until the Reformation. This progress includes the elimination of the "seven controvercial words" in the Preamble of the 1945 constitution, the so-called Piagam Jakarta, namely "the Indonesian state is based on the belief in the one, supreme God with the obligation the adherents of Islam to implement the shari " $a$ ". ${ }^{46}$ In the National Assembly Meeting (Sidang Umum) in 2001 and 2002, even Muhammadiyah and Nadlatul Ulama, the two biggest Indonesian Muslim organizations, rejected the proposals to enact the Islamic law. ${ }^{47}$ Progress can also be seen in the fact that Indonesia is the only country in the world which recognizes 6 official religions (Islam, Christianity, Protestantism, Hinduism, Buddhism, Confucianism) without any particular religion taking over the state. Confucianism was restricted in

${ }^{41}$ Abdullahi Ahmed An-Na'im, Islam and the Secular State, p. 223.

${ }^{42}$ Amin Abdullah "Celebrating Differences Through Dialogue in Indonesia: The Significant of Understanding Religions Today" (2009), unpublished paper, presented during the seminar entitled "Vatican-Indonesia Interfaith Dialogue" held by Sunan Kalijaga Islamic University Yogyakarta which invited Cardinal Jean-Louis Tauran.

${ }^{43}$ Suhadi Cholil, "Freedom of Religion or Belief in Indonesia after the Refora mation Era 1998”, (1998), Paper, unpublished.

${ }^{44}$ Peter L. Berger, "Foreword", in Nancy T. Ammerman (ed.), Everyday Religion:Observing Modern Religious Lives (New York: Oxford University Press, 2007), p. 9.

${ }^{45}$ Abdullahi Ahmed An-Na'im, Islam and the Secular State: Negotiating the Future of Sharia, p.97

${ }^{46}$ Ayzumardi, "Islamic Perspective on the Nation-State: Political Islam in PostSoeharto Indonesia," Al-Jamiah, No. 39 (2001), p. 306.

${ }^{47}$ Robert W. Heffner, "Muslim Democrats”, p. 298. 
the Soeharto era, but is at present legalized by the state via the Presidential Decision no. 6/2000. The freedom of religion or belief is safeguarded by the Indonesian government in the 1945 constitution. Additionally, Indonesians are permitted "to leave blank the religious identity line of the ID", and the possibility of indigenous religion adherents to register their marriage legally. ${ }^{48}$ The 2000 amendment became the umbrella for social, political, civil, and economic rights. This amendment adopts the structure of a Bill of rights which is similar to the Universal Declaration of Human Rights ${ }^{49}$ rather than any state-based shari ${ }^{6} a$ law found in this world. Finally, the published election results in 2004 revealed that fewer votes were obtained by Islamic parties and other religion-based parties than the nationalist or secular parties.

Within the gender mainstreaming framework, the Indonesian government genuinely implements the articles in the 1945 constitution, including equal rights to education, information, employment, and citizenship regardless of ethnicity, gender, or religious affiliations. Besides, the Indonesian state carries out the underlying regulations in CEDAW to fight discrimination against women as well. ${ }^{50}$ Unlike France and Iran which are still dealing with the issue of having a female president, the majority of Indonesians elected Megawati, an unveiled Muslim woman, as the first supreme leader in 2001, through a democratic and transparent election. Marie Elka Pangestu and Khofifah Indar Parawangsa also can be good examples of state neutrality in Indonesia in the sense of fair workforce competition. The first one is a non-Muslim Chinese woman trusted to be the Minister of Trade for two presidential periods (20042009 and 2009-2014), while the latter is a veiled Muslim woman appointed as the $5^{\text {th }}$ Minister of Women Affairs.

Likewise, in the dimension of education, the secular state universities never take the veil into account. They are only concerned

${ }^{48}$ Suhadi Cholil, "Freedom of Religion", pp. 5-11.

${ }^{49}$ Jeff Herbert, "The Legal Framework for Human Rights in Indonesia", in Tim Lindsey (ed.), Indonesian Law and Society (New South Wales: The Federation Press, 2008), p. 457.

${ }^{50}$ Based on Katjasungkana, Indonesia has endorsed the optional protocol of CEDAW in February 2000. Article 5 of CEDAW "imposes a positive duty on state parties to transform customs, practices, and attitudes that discriminate against women" (CEDAW, supra note 9, art.5) 
about the students' capability during the learning process. Some Christian and Muslim universities even bestow liberty for their female students who belong to different religions to take on the veil or not. It is also a common phenomenon in this modern era to see a veiled Muslim woman teaching in a Christian school and vice versa. From the elementary school until high school, students are taught religious subjects along with the "secular" curriculum. ${ }^{51}$ They are free to adopt the veil as part of their uniform or not. ${ }^{52}$

In the public domain, the state has established Komnas Perempuan (the National Commission for Women's Rights) ${ }^{53}$ to disseminate ideas about gender equality and to eradicate any kind of violence against women nationwide. ${ }^{54}$ Fueled by the freedom of speech, media, and NGO, Indonesia has succeeded in facilitating civic reason, including discourse on women's rights. So, it is not an exaggeration that Eldridge $e^{55}$ appreciates Indonesia's endeavor in terms of human rights protection in the past seven years since 1998.

Albeit each region is free to use the customary law and shari' $a$ to foster local and traditional norms within directly and indirectly-governed territories in Indonesia, ${ }^{56}$ its regional government must obey the national law and 1945 amendment. For regional cases, which are not related to national issues, the state cannot engage in the Adat courts. Hence, the regulation to wear the veil for both Muslim and non-Muslim in Aceh and Padang are exemptions of the freedom of religion and belief in Indonesia.

Properly speaking, Indonesia is a country which is well-suited to An-Na'im's version of secularism in several respects. First, the

${ }^{51}$ Azra, "Islamic Perspective", p. 300.

52 This is applicable only in state schools. In Indonesia, uniforms from elementary school until senior high school have their own color-based characteristics. These "universal uniforms" aim at getting rid of the social gap between the poor and the rich.

${ }^{53}$ In the beginning, Komnas Perempuan, protected by the Presidential Decree no. 181 of 1998, functioned only to solve racial tension against Chinese women during the 1998 May riots. Now it serves to empower women emancipation and is not limited to the Chinese community.

${ }^{54}$ Katjasungkana, as cited by Jeff Herbert, "The Legal Framework," p. 477.

${ }^{55}$ P. Eldridge, "Human Rights", The Brown Journal of World Affairs Vol. IX: (2002), p. 127.

${ }^{56}$ Sebastian Pompe, "Between Crime and Custom: Extra-Marital Sex in Modern Indonesian Law", in Tim Lindsey (ed.), Indonesian Law and Society, pp. 105-6. 
Indonesian government involves all citizens to express their opinion in public debate regarding particular issues. In fact, in the process of civic reason, Indonesian state is autonomous from certain groups, either religious or secular. Second, Indonesia embraces the communalism which enables its people to manifest their own tradition and religion without forgetting the spirit of nationalism. Third, the Indonesian state executes the principle of human-right-based citizenship, by means of "ensuring that all of inhabitants of the territory have general and equal obligations and entitlements in their relation to the state". ${ }^{57}$ The last, all parts of Indonesian society (Komnas Perempuan, media, civil society) have made the state supportive of women's rights and religious freedom through their active movements. Borrowing An-Na'im's idea, Indonesian society is the entity which has successfully rendered the state accountable for human rights.

\section{F. Concluding Remarks}

In summary, the abuse of power through universalism and failure of civic reason in France and Iran has violated women's entitlements in the sense of religious freedom. Indonesia, a Pancasila-based pluralist country, reflects An-Naim's secularism due to its success in giving equal rights for women.

The prohibition of the veil in France and the compulsion of chador in Iran are evidence of state hegemony to alienate the "foreign influence" by using women's body. The law is supposed to be the leading instrument to support human rights. But, the French and Iranian states "manipulate" the law of the veil to discriminate against women.

The ambiguous definition of "secularism" and "religion" created by France and Iran must be deconstructed. Meanwhile, the model of the Indonesian state bridges the gap between "secularism" and "religion". This country also welcomes constitutionalism and the dynamic progress of human rights.

${ }^{57}$ Abdullahi Ahmed An-Na'im, Islam and the Secular State, p. 88. 


\section{BIBLIOGRAPHY}

Abdullah, Amin, "Celebrating Differences Through Dialogue in Indonesia: The Significant of Understanding Religions Today", Paper, unpublished.

An-Na'im, Abdullahi Ahmed, Islam and the Secular State: Negotiating the Future of Shari'a. Cambridge: Harvard University Press, 2008.

Asad, Talal, Reading a Modern Classic: W.C. Smith's The Meaning and End of Religion, Chicago: University of Chicago, 2001.

Azra, Azzyumardi, "Islamic Perspective on the Nation-State: Political Islam in Post-Soeharto Indonesia", Al-Jamiah, 39: 306 (2001).

Baktiari, Bakman, "Dilemmas of Reform and Democracy in the Islamic Republic of Iran”, in Robert W. Hefner (ed.), Remaking Muslim Politics, Princeton, N.J.: Princeton University Press, 2005.

Berger, Peter L, "Foreword", in Nancy T. Ammerman (ed.), Everyday Religion: Observing Modern Religious Lives, New York: Oxford University Press, 2007.

Brenner, Suzanne, "Reconstructing Self and Society: Javanese Muslim Women and the Veil", American Ethnologist, Vol. 23, No. 4: 673 (1996).

Bullock, Katherine, Retbinking Muslim Women and the Veil, Richmond: The International Institute of Islamic Thought, 2003.

Cassanova, José, Public Religion in the Modern World, Chicago: University of Chicago Press, 1994.

Chehabi, H.E., "Religion and Politics in Iran: How Theocratic is the Islamic Republic?”, Daedalus 120: 69 (1991).

Cholil, Suhadi, "Freedom of Religion or Belief in Indonesia after the Reformation Era 1998: Its progress, Challenge, and Muslim Exceptionalism", paper, unpublished.

El Fadl, Abou Khaled, Speaking in God's Name: Islamic Law, Authority, and Women, Oxford: Bell \& Bain, 2001.

Eldridge, P., "Human Rights in Post-Suharto Indonesia", The Brown Journal of World Affairs IX: 127-139 (2002).

Ernst, Carl W., Following Mubammad: Rethingking Islam in the Contemporary World, London: the University of North Carolina Press, 2003. 
Faruqui, Munis D., "Iran: Renegotiating a 'Revolutionary Identity", Economic and Political Weekly 33: 2071 (1998).

Heffner, Robert W., "Muslim Democrats and Islamist Violence in PostSoeharto Indonesia", in Remaking Muslim Politics, Princeton, N.J: Princeton University Press, 2005.

Herbert, Jeff, "The Legal Framework for Human Rights in Indonesia”, in Tim Lindsey (ed.), Indonesia Law and Society, New South Wales: The Federation Press, 2008.

"Iran Sewot Terima Kritik Penyitaan Hadiah Nobel”, November 27, 2007.

"Mahinur Özdemir (CDH): On me diabolise à cause de mon foulard", Election 2009, May 26.

Mahmood, Saba, Politics of Piety: the Islamic Revival and the Feminist Subject, Princeton: Princeton University Pres, 2005.

Mehta, Pratap Bahnu, "On the Possibility of Religious Pluralism", in Thomas Banchoff (ed.), Religious Pluralism, Globalization, and World Politics, New York: Oxford University Press.

Pelletier, Dennis, “l'École, l'Éurope, les Corps: la laïcité et le voile”, Vingtième Siècle. Revue d'histoire 87: 162 (2005).

Pompe, Sebastian, "Between Crime and Custom: Extra-Marital Sex in Modern Indonesian Law", in Tim Lindsey (ed.), Indonesian Law and Society, New South Wales: The Federation Press, 2008.

Poulter, Sebastian, "Muslim Headscarves in School: Contrasting Legal Approaches in England and France", Oxford Journal of Legal Studies 17: 43-46 (1997).

Sakhroni, "Shirin Ebadi, Transcender of Divisive Boundaries", ISIM Newsletter, 13: 6-7 (2003).

Scott, Joan Wallach. 2007. The Politics of the Veil. Princeton, N.J.: Princeton University Press.

Sunder, Madhavi, "Piercing the Veil", The Yale Law Journal, 112: 1406 (2003).

“Tiga Perempuan Peneliti Indonesia Raih 'for Woman in Science”, Kompas, December 4, 2009. 